\title{
Struktur, Fungsi, dan Makna Talempong Bundo dalam Upacara Maanta Padi Saratuib
}

\author{
Wilma Sriwulan ${ }^{1}$ \\ Jurusan Musik, Institut Seni Indonesia Padang Panjang \\ Timbul Haryono, Victor Ganap, dan G.R. Lono L. Simatupang \\ Pengkajian Seni Pertunjukan dan Seni Rupa, Sekolah Pasca Sarjana, \\ Universitas Gadjah Mada Yogyakarta
}

\begin{abstract}
ABSTRAK
Talempong bundo adalah istilah untuk permainan musik talempong oleh sekelompok musisi perempuan di Nagari Singkarak Minangkabau. Permainan musik ini hanya dipertunjukkan dalam upacara maanta padi saratuih, yaitu upacara persembahan hasil panen yang dilakukan oleh perempuanperempuan dari pihak induak bako dalam rangkaian tradisi perkawinan anakpisangnya. Dalam upacara ini induak bako menjemput anak pisang, membawanya ke rumab bako, kemudian mengantarkan kembali dengan arak-arakan maanta padi saratuih. Talempong bundo merupakan satu-satunya musik prosesi yang dihadirkan dalam upacara itu, dan hingga saat ini kehadirannya masih dijunjung tinggi oleh masyarakat setempat. Fokus dari tulisan ini menjelaskan latar belakang kehadiran talempong bundo di dalam upacara maanta padi saratuih, melacak dan menjelaskan struktur talempong bundo dan relasi antar struktur secara fungsional, dan kemudian menjelaskan makna talempong bundo dalam upacara tersebut. Melalui teori fungsionalisme struktural A.R. Radcliffe-Brown dibantu dengan teori simbol Victor Turner diperoleh pemahaman bahwa prosesi arak-arakan maanta padi saratuih yang didukung oleh bunyi-bunyian talempong bundo mengumandangkan kepada masyarakat bahwa eksistensi pihak induak bako masih fenomenal di daerah tersebut. Talempong bundo merupakan simbol eksistensi pihak induak bako dalam konteks legitimasi terhadap anak pisangnya. Keberadaan talempong bundo dalam upacara maanta padi saratuih merupakan representasi sistem matrilineal dalam masyarakat Minangkabau di Nagari Singkarak.
\end{abstract}

Kata kunci: Talempong bundo, fungsionalisme struktural, induak bako, anak pisang, matrilineal

\begin{abstract}
The Structure, Function, and Meaning of Talempong Bundo in the Ceremony of Maanta Padi Saratuih. Talempong bundo is a term that is used for music performace of talempong by some female musicians in Nagari Singkarak, Minangkabau. The music is typically performed only in the ceremony of maanta padi saratuih, namely an offering ceremony for a rice harvest that is made by some women of induak bako in a context of their anak pisang, a tradition of its marriage ceremony. In this induak bako ceremony, anak pisang is picked up, taken to rumah bako, and then returned back with maanta padi saratuih procession. It is interesting that talempong bundo is the only ritual music that is played in the ceremony, and until now its existence is respected so much by the local community. The focus of this research is to explain a background of talempong bundo in the ceremony of maanta padi saratuih, to search and explore a structure of talempong bundo and inter-structure functionally, and then to describe the meaning of talempong bundo in the ceremony of maanta padi saratuih. With A.R. Radcliffe Brown's structural functionalism theory, supported by Victor Turner's symbol theory, it can be accepted that maanta padi saratuih procession enlivened by talempong bundo music performance announces to people of Nagari Singkarak specifically and Minangkabau people generally that induak bako's existence is still phenomenon in this area. Talempong bundo is a symbol of existence of induak bako's side for her legitimacy toward her anak pisang. Finally, an abstract reads that
\end{abstract}

1 Alamat korespondensi: Prodi Musik, ISI Padang Panjang. Jln. Bundo Kanduang, Padang Panjang. HP. 08126768409; E-mail:wilma_yyy@yahoo.co.id 
talempong bundo's existence in the ceremony of maanta padi saratuih is a proof of matrilineal kinship system among Minangkabau community in Nagari Singkarak.

Keywords: Talempong bundo, structural fungsionalism, induak bako, anak pisang, matrilineal

\section{Pendahuluan}

Upacara maanta padi saratuih merupakan suatu arak-arakan yang amat panjang dilakukan oleh puluhan perempuan dari kelompok induak bako. Ada oyak osen sebagai kepala adat, berbagai jamba adat yang ditata di atas dulang tinggi, ada kelompok talam sumandan, kambuik karambia, dan kambuik padi yang menjadi sajian utama dalam upacara itu. Semuanya dijunjung di atas kepala perempuan bako dalam mengiringi anakpisang yang berperan sebagai 'raja sehari'. Ada lagi kelompok pasumandan mudo sebagai pengiring pengantin membuat arak-arakan ini menjadi semakin menarik. Di balik semua itu, suasana kebesaran upacara terbangun oleh bunyi-bunyian talempong yang dimainkan oleh para musisi perempuan yang menjadi bagian dari struktur upacara tersebut. Sekelompok masyarakat Minangkabau di Nagari Singkarak dalam sebuah seremoni adat yang merepresentasikan keterkaitan hubungan antara induak bako dan anak pisang.

Demikian sekelumit gambaran upacara maanta padi saratuih, yaitu suatu seremoni adat yang sudah menjadi tradisi masyarakat Minangkabau di Nagari Singkarak (Simatupang, 2003; Mardimin , 1994: 145). Masyarakat yang menjadi sangat unik dan khas karena prinsip keturunan matrilineal yang dianutnya berbeda dengan suku-suku bangsa lainnya di Indonesia. Artinya, keturunan didasarkan pada garis ibu (perempuan) (Kato, 1982: 7). Oleh sebab itu, perempuan Minangkabau mempunyai kedudukan dan peranan tersendiri dalam adat-istiadat yang ditumbuhkembangkan oleh masyarakatnya.

Rentetan dari hasil perkawinan suku bangsa Minangkabau ini menimbulkan hubungan kekerabatan antara keluarga istri dengan keluarga rumah gadang (rumah adat) suami, dan sebaliknya antara keluarga suami dan keluarga rumah gadang istri. Termasuk orang- orang yang menikah dengan pihak keluarga suami dan pihak keluarga istri. De Jong (1960: 65).menyatakan bahwa sistem sosial masyarakat Minangkabau menunjukkan perkawinan berputar yang setidaknya melibatkan tiga klen (suku). Meskipun ada lebih banyak klen yang bergabung dalam suatu lingkaran perkawinan, namun setiap individu selalu harus menghadapi tiga klen yang jauh lebih besar baginya daripada semua yang lain; klennya, klen tempat dia mendapatkan istri, dan klen tempat saudarinya menemukan suami. Dengan kata lain: klennya, klen pemberi istri, dan klen pengambil istri.

Dalam sistem sosial perkawinan berputar tersebut, sering ada istilah khusus bukan hanya untuk menunjuk kelompok seseorang, tetapi juga dua kelompok lain yang saling berhubungan erat. Hubungan kekerabatan itu menimbulkan tali kerabat seperti hubungan induak bako/bako dan anak pisang, hubungan sumando (semua laki-laki yang menjadi suami dari perempuan yang sekaum) dan pasumandan (semua perempuan yang menjadi istri dari laki-laki yang sekaum), hubungan ipa dan bisan disingkat pabisan (ipar dan besan), serta hubungan mintuo dan minantu (mertua dan menantu).

Istilah induak bako (kadang disebut bako kontan) dipergunakan untuk menyebut keluarga inti matrilineal ayah atau saudara-saudara perempuan yang sekandung dengan ayah, sedangkan istilah bako mengacu kepada sanak saudara yang sesuku dengan ayah. Induak bako/bako menyebut anak pisang kepada anak-anak dari saudara laki-laki mereka dengan istrinya dari klen (suku) lain (Pamoentjak, 1935: 15). Hubungan antara induak bako/bako dengan anak pisang sangatlah dekat, hubungan ini terutama terlihat dari induak bako yang perempuan kepada anak pisangnya, baik anak pisang yang laki-laki maupun yang perempuan. De Jong (1960: 65) mengungkapkan bahwa induak 
bako atau keluarga suami menunjukkan dualisme yang menyolok terhadap istri. Ada kewajiban induak bako (orang tua suami) untuk selalu membantu menantu putrinya. Induak bako selalu memberikan kehormatan dalam pemukiman komunal kepada para anggota kelompok pasumandan. Mereka selalu hormat kepada anak pisangnya — dan pada berbagai upacara akan memberikan hadiah kepadanya. Bagan 1 memperjelas keterkaitan hubungan kekerabatan antara induak bako dan anak pisang.

Bagi masyarakat Nagari Singkarak Minangkabau kedekatan hubungan antara induak bako dan anak pisang ini terefleksikan dalam upacara maanta padi saratuih, suatu upacara yang merupakan rangkaian dari tradisi adat perkawinan anak pisang. Dalam upacara ini induak bako (saudara-saudara perempuan ayah) menjemput anak pisangnya yang sudah menikah beberapa hari sebelumnya, kemudian membawanya ke rumah bako. Di rumah bako, anak pisang dimandikan dengan ritual mandi balimau (Minang: limau/jeruk, adalah memandikan anak pisang dengan air yang diberi potongan tujuh macam jeruk, dan hanya dilakukan kepada anak pisang yang perempuan), dirias, dipasangkan pakaian pengantin, kemudian diantar kembali ke rumah orang tuanya dengan arak-arakan maanta padi saratuih. Arak-arakan ini disertai dengan persembahan hasil panen (Lihat Keesing, 1992: 11-13) dari induak bako yang mengusung padi saratuih sukek (padi seratus sukat) sebagai persembahan utama. Anak pisang diarak sekeliling kampung oleh bako-bako perempuan pelaku upacara dengan iringan musik talempong yang juga dimainkan oleh sekelompok musisi perempuan, lazim disebut talempong bundo.

Kehadiran talempong bundo dalam upacara maanta padi saratuih merupakan fenomena budaya yang menarik dan unik. Dikatakan menarik karena relevansinya dalam kehidupan masyarakat Nagari Singkarak, bahwa masyarakat setempat masih memfungsikannya hingga sekarang. Talempong bundo merupakan penopang wajib dalam tradisi ini, tidak ada upacara maanta padi saratuih yang dilaksanakan tanpa talempong bundo. Masyarakat beranggapan bahwa arak-arakan tanpa "bunyibunyian" dianggap sebagai arak-arakan yang mengantar duka (kematian).

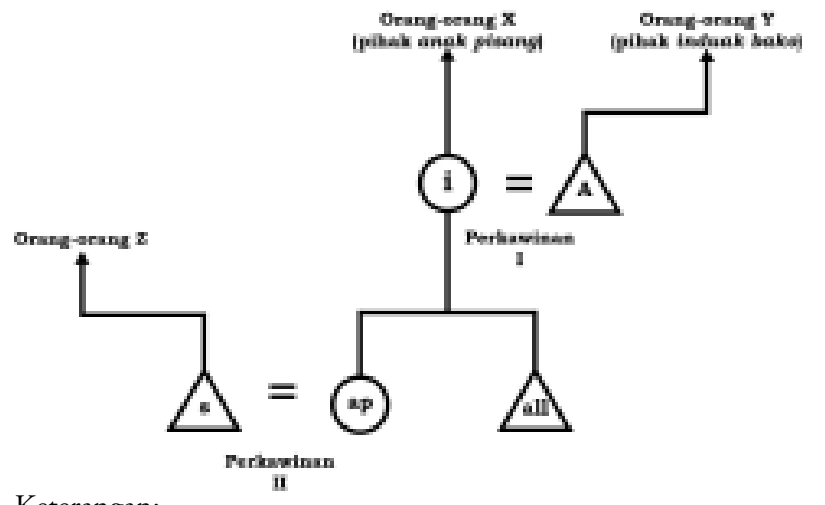

Keterangan:

$\mathrm{i}=\mathrm{ibu}$

= pasumandan dari orang-orang $\mathrm{Y}$

$\mathrm{A} \quad=$ ayah

= sumando dari orang-orang $\mathrm{X}$

ap = anak perempuan

= anak pisang dari orang-orang $\mathrm{Y}$

= pasumandan dari orang-orang $Z$

all $\quad=$ anak laki-laki

= anak pisang dari orang-orang $\mathrm{Y}$

= suami

= sumando dari orang-orang $\mathrm{X}$

Orang-orang $\mathrm{X}=$ pihak anak pisang

Orang-orang $\mathrm{Y}$ = pihak induak bako

Orang-orang $\mathrm{Z}$ = pihak suami ap atau sumando

Bagan 1. Bagan hubungan kekerabatan antara induak bako dan anak pisang. (Adaptasi dari Keesing, 1992: 12)

Bagi masyarakat Nagari Singkarak Minangkabau kedekatan hubungan antara induak bako dan anak pisang ini terefleksikan dalam upacara maanta padi saratuih, suatu upacara yang merupakan rangkaian dari tradisi adat perkawinan anak pisang. Dalam upacara ini induak bako (saudara-saudara perempuan ayah) menjemput anak pisangnya yang sudah menikah beberapa hari sebelumnya, kemudian membawanya ke rumah bako. Di rumah bako, anak pisang dimandikan dengan ritual mandi balimau (Minang: limau/jeruk, adalah memandikan anak pisang dengan air yang diberi potongan tujuh macam jeruk, dan hanya dilakukan kepada anak pisang yang perempuan), dirias, dipasangkan pakaian pengantin, kemudian diantar kembali ke rumah orang tuanya dengan arak-arakan maanta padi saratuih. Arak-arakan ini disertai dengan persembahan hasil panen (Lihat Keesing, 1992: 11-13) dari induak bako yang mengusung padi saratuih sukek (padi seratus sukat) sebagai persembahan utama. Anak pisang diarak sekeliling kampung oleh bako-bako perempuan pelaku upacara dengan iringan musik talempong yang juga dimainkan oleh sekelompok musisi perempuan, lazim disebut talempong bundo. 
Kehadiran talempong bundo dalam upacara maanta padi saratuih merupakan fenomena budaya yang menarik dan unik. Dikatakan menarik karena relevansinya dalam kehidupan masyarakat Nagari Singkarak, bahwa masyarakat setempat masih memfungsikannya hingga sekarang. Talempong bundo merupakan penopang wajib dalam tradisi ini, tidak ada upacara maanta padi saratuih yang dilaksanakan tanpa talempong bundo. Masyarakat beranggapan bahwa arak-arakan tanpa "bunyibunyian” dianggap sebagai arak-arakan yang mengantar duka (kematian).

\section{Struktur dan Fungsi Pertunjukan Talempong Bundo}

Pemahaman tentang 'pertunjukan' di sini merujuk pada aktifitas-aktifitas 'simbolik' atau 'estetis' khusus, seperti aktifitas-aktifitas ritual atau teatrikal dan aktifitas-aktifitas seni rakyat, yang dijalankan sebagai produk ekspresi yang sengaja di dalam genre lokal yang telah mapan (Schiefellin dalam Hughes-Freeland, 1998: 194). Bauman (Schiefellin, 1998: 194) mengenali ciri-ciri pertunjukan sebagai tampilan kemampuan atau keterampilan ekspresi oleh satu pemain atau lebih yang disampaikan kepada sebuah audiens. Peristiwa pertunjukan ini disebut oleh Simatupang (2006) sebagai peristiwa ambang batas, yaitu peristiwa yang nyata akan tetapi berbeda dengan yang dijumpai dalam kehidupan sehari-hari. Menurut Turner (Simatupang, 2006), orang menikmati dan melakukan pertunjukan atau peristiwa ambang batas tersebut karena di dalamnya berlangsung berbagai hal yang memungkinkan orang untuk merefleksikan berbagai hal perihal diri, orang lain, masyarakat, dan dunia yang dihidupinya.

Demikian juga halnya dengan pertunjukan talempong bundo dalam upacara maanta padi saratuih. Talempong ini hanya dipertunjukkan apabila ada induak bako yang menjemput anak pisang dalam rangkaian tradisi adat perkawinannya. Murgiyanto (1996: 153) dan Hendri (2001: 84) menyebut pertunjukan jenis ini sebagai cultural performance (pertunjukan budaya) yang kontekstu$\mathrm{al}$, adalah pertunjukan yang selalu terkait dengan upacara adat yang dilaksanakan masyarakat pemi- liknya. Oleh karenanya kajian terhadap pertunjukan talempong bundo, difokuskan pada bagaimana perorangan dan kelompok masyarakat Nagari Singkarak dalam kehidupannya sehari-hari memberi bentuk terhadap nilai-nilai yang dihayatinya (dirasakan secara mendalam) menjadi bentuk-bentuk yang artistik dan bermakna.

Upacara maanta padi saratuih mempunyai struktur yang terdiri atas beberapa unsur, masingmasing unsur itu saling berhubungan dan menentukan satu sama lainnya. Setiap unsur merupakan bagian dari unsur yang lebih besar, dan sekaligus memiliki unsur yang lebih kecil. Masing-masing unsur itu juga memiliki struktur masing-masing. Apabila diaplikasikan dengan pandangan RadcliffeBrown (1980: 221) bahwa secara bertingkat talempong bundo didudukkan sebagai bagian dari lapisan struktur yang lebih besar, yaitu struktur upacara maanta padi saratuih, di atasnya ada struktur perkawinan, dan selanjutnya ada struktur sosial dan realitas sosial masyarakat Nagari Singkarak sebagai struktur terbesar. Fenomena ini mirip dengan istilah masyarakat berbingkai seperti yang diutarakan oleh Peter L. Berger (1985) bahwa di dalam suatu masyarakat terdapat kelompok masyarakat lain yang lebih kecil.

Sebagai bagian dari struktur tradisi adat perkawinan masyarakat Nagari Singkarak, upacara maanta padi saratuih terdiri dari beberapa unsur, yaitu: (1) Persiapan di rumah anak pisang, seperti mambantai (memotong kambing atau sapi yang dihadiri oleh seluruh kaum laki-laki di nagari) dan persiapan hidangan alek (pesta) menunggu rombongan arak-arakan induak bako dan masyarakat kampung; (2) Persiapan benda-benda dan perlengkapan upacara di rumah bako (rumah keluarga matrilineal ayah), seperti persiapan jamba adat (berbagai masakan adat), nasi putiah (nasi putih), nasi kunyik (nasi kunyit), kambuik balamun (persembahan dari pasumandan dekat, yaitu perempuan-perempuan yang menjadi istri laki-laki dari pihak induak bako), talam sumandan (persembahan dari pasumandan jaub), kambuik karambia (bakul kelapa), kambuik padi (bakul padi), oyak osen (properti yang dimaknai sebagai kepala adat), dan talempong; (3) Manjapuik anak pisang (menjemput anak pisang) ke rumah orang 
tuanya, kemudian membawa ke rumah bako; (4) Mandi balimau yang lazimnya dilakukan oleh nenek bako (orang tua dari ayah) dan hanya dilakukan kepada anak pisang yang perempuan; (5) Merias anak pisang; (6) Arak-arakan maanta padi saratuib; dan (7) Penyambutan di rumah anak pisang. Relasi ketujuh unsur-unsur tersebut dapat dilihat seperti bagan 2.

Bagan 2 menunjukkan struktur upacara maanta padi saratuih yang terdiri dari beberapa unsur. Unsur-unsur tersebut merupakan sistem relasi sintagmatik sekaligus paradigmatik antara peristiwa yang satu dengan yang lainnya. Pelaksanaannya tidak boleh dibolak-balik karena harus dilakukan secara runtut, kecuali dua peristiwa persiapan di rumah anak pisang dan persiapan di rumah bako yang dilakukan pada waktu yang bersamaan. Masing-masing peristiwa di atas melibatkan berbagai persoalan karena memiliki struktur tersendiri dan tata cara peristiwa yang berbeda satu sama lainnya. Demikian juga dengan pelaku atau pelaksana upacara, jenis dan peralatan upacara yang digunakan, serta tujuan upacara.

Kehadiran talempong bundo di dalam upacara ini amat penting dan menunjang maksud penyelenggaraan upacara adat tersebut. Talempong bundo dan upacara maanta padi saratuih saling terjalin secara fungsional, tidak pernah berdiri sendiri terlepas dari upacara itu. Dalam konteks upacara ini talempong bundo dipertunjukkan dua kali. Pertama, saat merias anak pisang; dan kedua, dalam arak-arakan maanta padi saratuih. Pertunjukan talempong bundo dalam kedua aktifitas tersebut dihargai sebagai sebuah unsur yang masing-masing memiliki struktur dan fungsi berbeda. Kehadirannya diaktualisasikan dalam keseluruhan peristiwa ini. Oleh karena itu dalam pembahasan talempong bundo ini, pertunjukan merupakan persoalan yang utama.

\section{Pertunjukan Talempong Bundo Saat Merias}

\section{Anak Pisang}

Pertunjukan talempong bundo dalam upacara maanta padi saratuih sebagai bagian dari rangkaian tradisi perkawinan lazim diselenggarakan setelah panen padi. Karena pada daerah-daerah agraris musim perkawinan pada umumnya dilakukan setelah panen (A.A. Navis, 1984: 203). Setiap setelah panen bako selalu 'menabung padi' untuk para anak pisangnya yang akan menikah di dalam jangka waktu sampai panen berikutnya. Istilah 'menabung padi' di sini diartikan bahwa bako akan menyimpan padi hasil panen saat itu untuk dipersiapkan bagi anak pisang yang sudah saatnya menikah. Setiap bako akan memilih padi terbaik untuk ditabung bagi anak pisangnya. Diharapkan padi yang dihadiahkan tersebut apabila ditanam oleh anak pisang akan mendapatkan hasil yang berlimpah, sehingga akan dapat memenuhi kebutuhan primer dalam rumah tangga.

Sebagai kegiatan ritual yang amat dihormati, upacara maanta padi saratuih lazimnya dilaksanakan pada hari Senin, Kamis, atau Sabtu. Ketiga hari itu dianggap sebagai hari yang tepat untuk melaksanakan upacara maanta padi saratuih. Pemilihan harihari tersebut sudah merupakan kesepakatan kolektif masyarakat Nagari Singkarak. Biasanya hari Jumat dianggap sebagai hari terbaik dalam seminggu. Oleh karena kepercayaan yang demikian masyarakatpun memilih hari itu untuk melakukan segala yang dianggap suci, umpamanya untuk melangsungkan hari pernikahan (Navis, 1984: 202). Apabila pesta yang diadakan menggunakan undangan yang diperuntukkan bagi tamu-tamu luar (selain dari masyarakat Nagari Singkarak), maka kegiatan ini dilakukan pada hari Minggu.

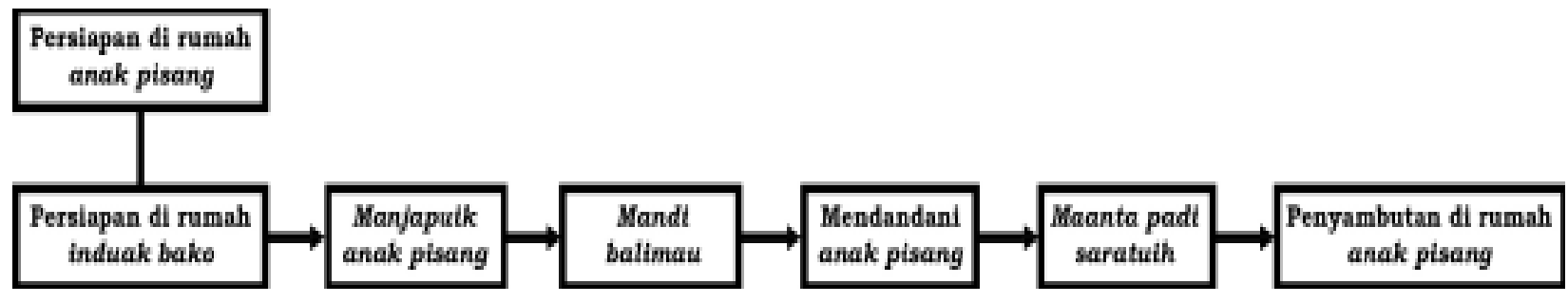

Bagan 2. Unsur-unsur pelaksanaan upacara maanta padi saratuih 
Format upacara maanta padi saratuih ini telah disepakati sebelumnya, mungkin saja yang sedang melaksanakan perkawinan adalah anak pisang yang perempuan, atau anak pisang yang laki-laki. Baik anak pisang yang perempuan ataupun anak pisang yang laki-laki bisa saja dijemput induak bako dengan upacara maanta padi saratuih. Semuanya tergantung dari keinginan induak bako untuk menjemput anak pisangnya yang kemudian disepakati oleh kedua orang tua anak pisang.

Kelompok talempong bundo selalu dipertunjukkan dalam aktifitas ini. Kelompok telempong ini terdiri atas empat orang pemain, tiga pemain talempong dan satu pemain adok. Ketiga pemain talempong masing-masing disebut sebagai pemain talempong anak, pemain talempong tangah, dan pemain talempong induak. Kelompok talempong bundo sebagai musik yang mengiringi upacara sudah berada di rumah bako bertepatan dengan dimulainya proses merias anak pisang. Pertunjukan pertama talempong bundo ini biasanya bersamaan dengan saat anak pisang mulai dirias, yakni setelah dilakukan ritual mandi balimau (bagi anak pisang yang perempuan).

Dalam sebuah tradisi adat perkawinan, seorang anak pisang yang berperan sebagai anak daro (pengantin perempuan) mulai dirias oleh tukang suntiang (tukang rias pengantin) sekitar pukul 09.00 W.I.B. pagi. Bersamaan dengan itu kelompok musik talempong bundo pun mulai memainkan talempongnya.

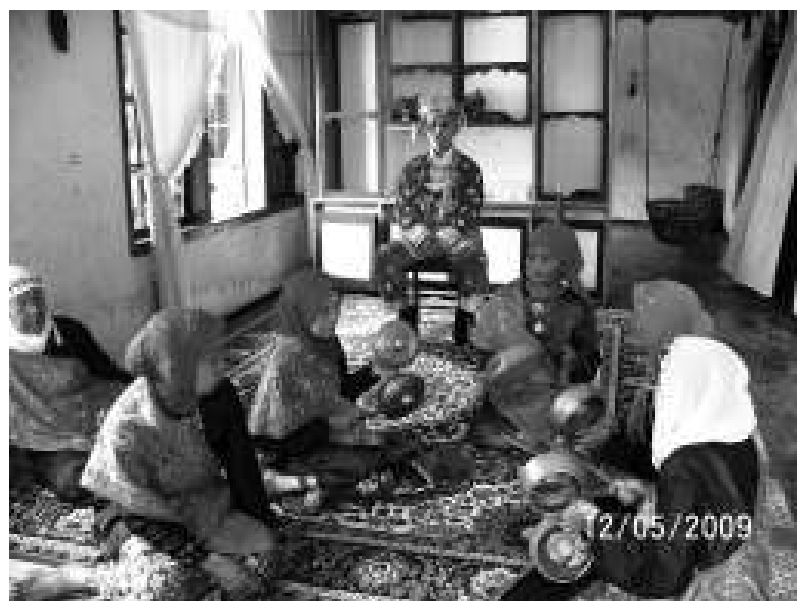

Gambar 2. Pertunjukan pertama talempong bundo ketika anak pisang laki-laki yang dijemput induak bako.

(Foto: Wilma Sriwulan, 2009)

'Panggung pertunjukan' yang dipergunakan di dalam rumah bako tidak dipersiapkan sebagaimana panggung seni pertunjukan umumnya, karena pertunjukan dapat dilakukan pada posisi mana saja di dalam rumah bako. Lazimnya, posisi anak pisang dirias di bagian kepala rumah (anjuang pada rumah gadang). Di tempat tersebut diletakkan satu atau dua buah kursi, dan di sanalah proses merias dilakukan. Di depan anak pisang, kelompok talempong bundo duduk bersimpuh berempat dan memulai pertunjukannya. Pada posisi yang demikian para induak bakolbako yang menonton dapat menyaksikan pertunjukan talempong bundo ini dari arah mana saja, baik dari arah samping kiri, samping kanan, maupun depan. Pada gambar 3 dapat dilihat posisi anak pisang, talempong bundo, dan bako sebagai pelaku upacara.
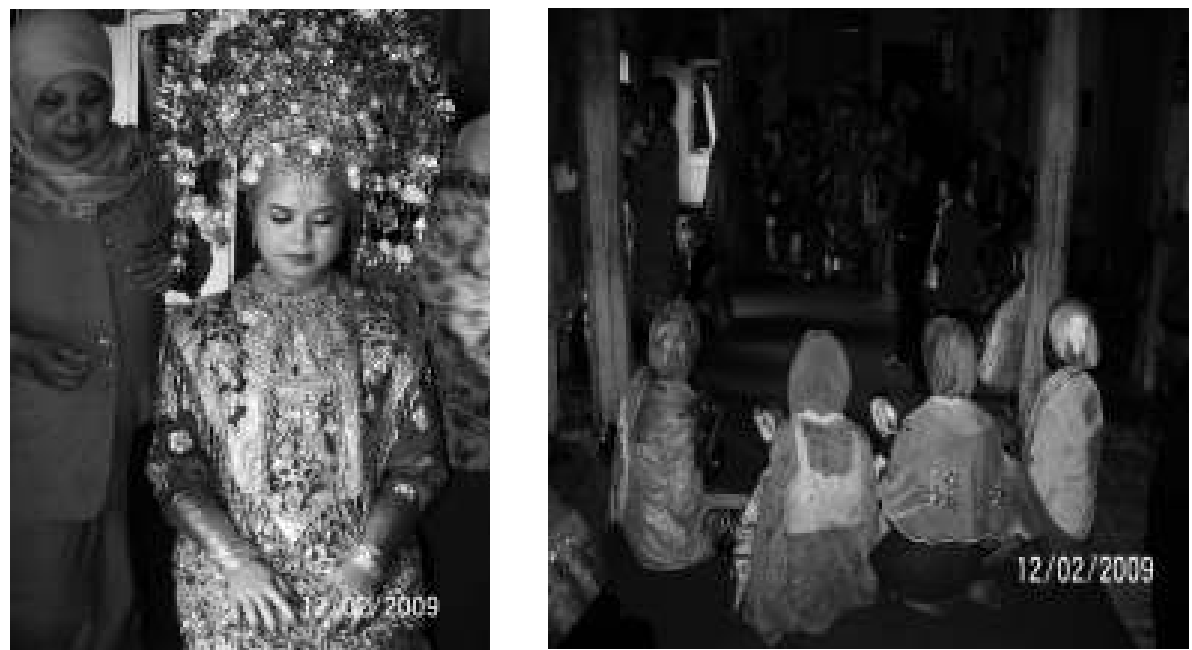

Gambar 1. Pertunjukan pertama talempong bundo ketika anak pisang perempuan sedang dirias (Foto: Wilma Sriwulan, 2009) 


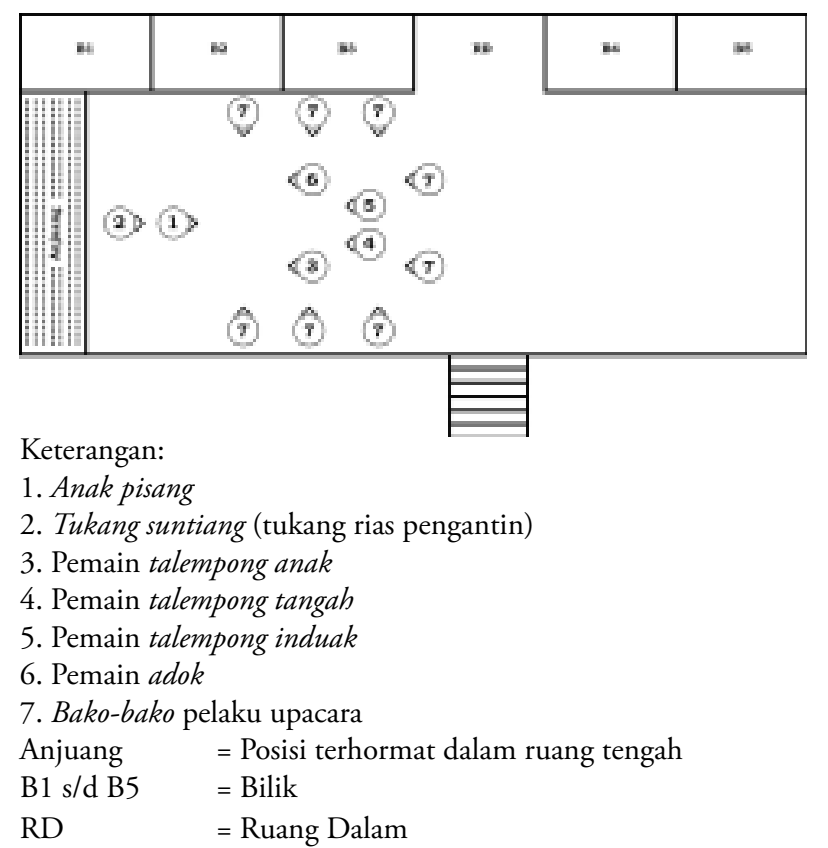

Gambar 3. Bagan pertunjukan talempong bundo saat merias anak pisang

Berdasarkan posisi altar dan situasi rumah gadang pada saat merias anak pisang, disadari atau tidak, di sini terdapat perbedaan area. Anak pisang yang sedang dirias didudukkan di depan anjuang yaitu posisi paling utama dan terhormat di dalam rumah gadang. Ini menunjukkan bahwa anak pisang merupakan sosok yang istimewa. Perempuan-perempuan musisi talempong bundo duduk di tengahtengah ruangan berhadapan dengan anakpisang. Bako-bako pelaku upacara mengambil tempat di hadapan anak pisang membentuk setengah lingkaran mulai dari samping kiri, depan, dan samping kanan mengelilingi anak pisang dan talempong bundo.

Dari fenomena ini dapat dipahami bahwa bako-bako pelaku upacara yang muncul setelah mendengarkan bunyi talempong datang untuk memberi kekuatan kepada talempong bundo dalam rangka mendoakan, mensucikan, atau mengistimewakan anak pisang dalam hubungannya dengan ritual ini. Oleh sebab itu anak pisang dapat diposisikan pada posisi yang paling atas, talempong bundo pada posisi tengah, dan induak bakolbako pada posisi paling bawah. Jika anak pisang dipandang sebagai yang di atas, talempong bundo yang di tengah, dan induak bako sebagai penyangga yang berada di

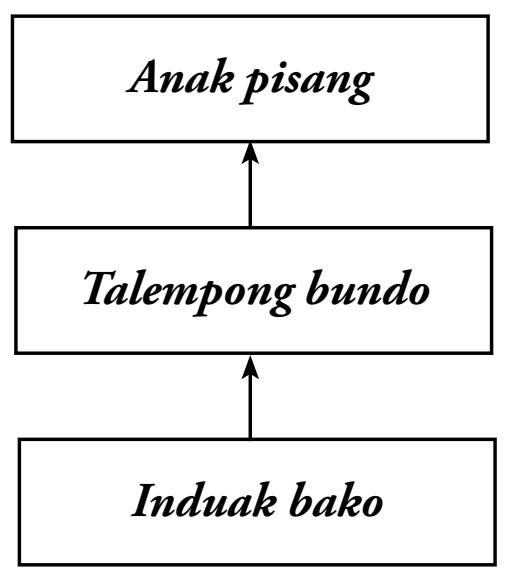

Gambar 4. Struktur tiga kerangka relasional permainan talempong bundo saat merias anak pisang

bawah, maka dari relasi semacam ini ditemukan sebuah pola tiga yang disusun secara vertikal (Gambar 4).

Gambar 4 menunjukkan bahwa anak pisang berada pada posisi paling atas, yaitu posisi yang utama dan istimewa. Kehadiran bako-bako pelaku upacara adalah untuk memperkuat talempong. Para bako tersebut hadir karena talempong sudah berbunyi. Dengan demikian dapat dikatakan bahwa talempong bundo itu merupakan mediasi antara induak bako dan anak pisang. Relasi-relasi antar struktur ini disatukan karena anak pisang yang istimewa diasosiasikan pada tempat yang di atas, induak bako pada posisi yang di bawah, maka talempong bundo sebagai mediasi berada di tengah. Sehingga muncullah struktur atas, tengah, dan bawah seperti di atas.

Interaksi antara talempong dengan induak bako/bako pelaku upacara muncul pada saat itu, yaitu makin lama bako-bako perempuan pelaku upacara makin banyak berdatangan. Struktur bako jauh maupun dekat, pasumandan-pasumandan bako yang jauh maupun dekat tidak terjadi secara kebetulan, akan tetapi sudah ada sesuai dengan sistem kekerabatan mereka. Struktur tersebut dapat dilihat dari pakaian para pelaku upacara tersebut, dari barang-barang persembahan yang dibawa mereka, dari cara induak bako memperlakukan mereka, dan sebagainya.

Semakin siang semakin banyak pula bako yang datang, selain mengisi ruang tengah tempat anak pisang dirias, para bako ini juga mengitari 
halaman, pinggir-pinggir jalan menunggu waktu pelaksanaan arak-arakan. Semakin banyak bako-bako dan para pasumandan yang datang, maka semakin banyak pula penonton yang menyaksikan pertunjukan talempong itu, karena para bako dan pasumandan-pasumandan yang datang sekaligus menjadi penonton dalam rangkaian aktifitas tersebut.

Permainan talempong bundo saat anak pisang dirias ini terus-menerus disajikan antara gua (lagu) yang satu dengan gua berikutnya. Gua-gua yang dimainkan pada saat itu tidak ditentukan sebelumnya, karena semua tergantung pada suasana hati dan kesepakatan seluruh anggota kelompok musik ini. Ada beberapa buah gua yang dimainkan oleh kelompok Talempong bundo Jorong Tampunik yang sengaja diundang dalam aktivitas ini, yaitu: (1) Gua Rami; (2) Gua Tari Piriang; dan (3) Gua Pulang Baliak. Ketiga gua ini dimainkan selama anak pisang dirias. Selesai gua yang pertama dimainkan kemudian dilanjutkan secara berturut-turut dengan gua yang kedua dan yang ketiga. Walau diselingi beberapa saat untuk jeda minuman yang disuguhkan oleh induak bako, namun selanjutnya talempong dimainkan kembali oleh para musisi perempuan itu.

Sekitar pukul 11.00 W.I.B. anak pisang telah selesai dirias, seluruh pelaku arak-arakan sudah hadir di tempat. Demikian juga dengan perlengkapan upacara, semuanya sudah selesai dipersiapkan. Namun talempong masih tetap dimainkan hingga datang nasi panjapuik bako (nasi penjemput $b a k o$ ) yang diantarkan oleh dua orang perempuan utusan pihak keluarga anak pisang ke rumah bako. Nasi panjapuik bako ini terdiri atas semangkok nasi dan semangkok gulai kambing yang dibantai (dipotong) pada pagi harinya di rumah anak pisang. Selain merupakan bagian dari adat, nasi panjapuik bako ini juga merupakan salah satu simbol penghargaan pihak keluarga anak pisang terhadap induak bako, bahwa sebelum gulai kambing disuguhkan kepada tamu, maka diberi penghormatan kepada induak bako untuk mencicipinya terlebih dahulu. Kedatangan nasi panjapuik bako juga merupakan pertanda bahwa keluarga anak pisang telah siap menerima kedatangan induak bako dan rombongan arak-arakan. Selain sebagai isyarat untuk memulai arakarakan maanta padi saratuih, juga merupakan isyarat bagi para musisi talempong bundo untuk mengakhiri pertunjukan pertama mereka jelang siang itu. Berhentinya bunyi talempong menandakan bahwa arak-arakan maanta padi saratuih segera dimulai. Nenek bako (orang tua dari ayah) selaku perempuan yang mempimpin upacara ini mengisyaratkan kepada semua pelaku upacara untuk segera turun ke jalan karena sudah waktunya arak-arakan dimulai.

\section{Pertunjukan Talempong Bundo dalam Arak- Arakan Maanta Padi Saratuib}

Sebagai bagian dari struktur upacara maanta padi saratuih, tempat pertunjukan talempong bundo otomatis sama dengan tempat pelaksanaan arak-arakan maanta padi saratuih, yaitu sepanjang perjalanan dari rumah bako sampai ke rumah anak pisang. Jalur yang akan ditempuh telah disepakati terlebih dahulu oleh seluruh pelaku upacara. Pemilihan jalur tersebut disesuaikan dengan kemampuan anak pisang (anak daro atau marapulai) yang diarak dengan pakaian pengantinnya, dan kemampuan bako yang menjunjung padi. Pemilihan terhadap jalan yang akan dilalui sebelumnya telah ditentukan oleh induak bako, dengan sasaran agar bisa dilihat oleh masyarakat banyak.

Sesuai dengan pengungkapan sebelumnya bahwa posisi bako-bako pelaku arak-arakan secara terstruktur dari depan ke belakang terdiri atas: (1) Penjunjung oyak osen (properti yang dianggap sebagai kepala adat); (2) Penjunjung jamba adat (berbagai masakan adat); (3) Penjunjung nasi putiah (nasi putih); (4) Penjunjung nasi kunyik (nasi kunyit); (5) Kelompok penjunjung kambuik balamun yang dibawa oleh pasumandan-pasumandan dekat; (6) Kelompok penjunjung talam sumandan yang dibawa oleh pasumandan-pasumandan jauh; (7) Kelompok pasumandan-pasumandan mudo (perempuan-perempuan muda yang menjadi istri dari laki-laki pihak bako) sebagai pengiring pengantin; (8) Anak pisang yang menjadi 
pengantin didampingi oleh dua orang induak bako; (9) Kelompok pasumandan-pasumandan mudo berikutnya; (10) Kelompok penjunjung kambuik karambia (bakul kelapa); (11) Kelompok penjunjung kambuik padi (bakul padi); dan (12) Kelompok musik talempong bundo. Urutan prosesi maanta padi saratuih dari rumah bako menuju rumah anak pisang ini dapat disederhanakan seperti gambar 5 .

Rute arak-arakan maanta padi saratuih bergerak mulai berangkat dari rumah bako, mengelilingi kampung, hingga sampai ke rumah orang tua anak pisang. Rute arak-arakan tersebut dapat dilihat pada gambar 6.

Pelaku arak-arakan pada umumnya adalah seluruh perempuan-perempuan dari pihak induak bako. Lain halnya posisi pelaku musik tradisional talempong bundo sebagai musik prosesi dalam upacara ini. Kelompok musisi talempong bundo ini diundang secara khusus untuk menjadi bagian dari struktur upacara sekaligus mendukung pelaksanaan upacara maanta padi saratuih. Di sini kelompok musik talempong bundo menempati posisi urutan tertentu pada bagian belakang arak-arakan sesuai dengan karakter dari suatu iring-iringan prosesi arak-arakan tersebut. Demikian juga halnya dengan perempuan pembawa oyak osen, sebagai orang yang diundang secara khusus posisinya berada pada bagian paling depan, sesuai dengan fungsi oyak osen sebagai kepala adat.

\begin{tabular}{|c|c|c|c|c|c|c|c|c|c|c|c|}
\hline XIIa & & & & IX & & & & & & & \\
\hline XIIb & \multirow{2}{*}{ XI } & \multirow{2}{*}{$\mathbf{X}$} & \multirow{2}{*}{ VII } & \multirow{2}{*}{ VIII } & \multirow{2}{*}{ VII } & \multirow{2}{*}{ VI } & \multirow{2}{*}{ V } & \multirow{2}{*}{ IV } & \multirow{2}{*}{ III } & \multirow{2}{*}{ II } & \multirow{2}{*}{ I } \\
\hline XIIc & & & & & & & & & & & \\
\hline XIId & & & & IX & & & & & & & \\
\hline
\end{tabular}

Keterangan:
I. Penjungjung oyak osen
II. Penjunjung jamba
III. Penjungjung nasi putiah
IV. Penjunjung nasi kunyik
V. Kelompok penjunjung kambuik balamun
VI. Kelompok penjunjung talam sumandan
VII. Kelompok pasumandan mudo
VIII. Anak pisang (anak daro/marapulai)

IX. Induak bako (pendamping)

$\mathrm{X}$. Kelompok penjunjung karambia

XI Kelompok penjunjung kambuik padi

XIIa. Pemain talempong anak

XIIb. Pemain talempong tangah

XIIc. Pemain talempong induak

XIId. Pemain adok

Gambar 5. Urutan prosesi arak-arakan maanta padi saratuih dari rumah bako ke rumah anak pisang

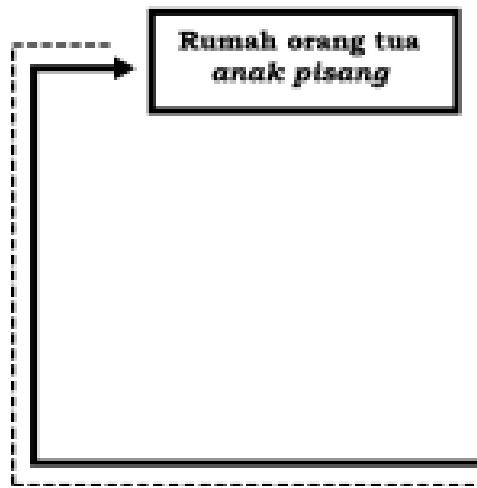


Upacara maanta padi saratuih adalah tradisi yang sudah akrab dengan masyarakat, sehingga seluruh lapisan masyarakat telah memahami struktur pelaksanaan arak-arakan ini. Pemahaman masyarakat terhadap struktur prosesi ini dapat dilihat dari mulai persiapan pelaksanaan arak-arakan. Para pelaku arakarakan tanpa dikomando akan mengambil posisi masing-masing sesuai dengan peranannya. $\mathrm{Hal}$ ini juga dapat dilihat pada saat prosesi arakarakan sedang berlangsung, bahwa apabila ada pelaku arak-arakan yang terlambat datang maka ia akan menyesuaikan diri dengan struktur arakarakan, sehingga tidak mengganggu kelancaran prosesi.

Arak-arakan maanta padi saratuih ini akan ditonton oleh masyarakat sekeliling kampung. Bunyi talempong yang terdengar memberikan petunjuk kepada masyarakat tentang adanya penyelenggaraan upacara maanta padi saratuih. Masyarakat yang mendengarkan bunyi talempong itu akan mempertanyakan rajo ma pulo nan turun (raja mana pula yang turun?)_adalah sebuah pertanyaan yang mengandung makna bahwa pengantin itu dianggap sebagai seorang Raja, yaitu 'raja sehari'. Seperti dalam pantun yang menyebutkan bahwa: Mandanga talempong nan lah datang, baraso rajo nan tibo ... (Mendengar talempong yang sudah datang, berasa raja yang tiba). Pantun di atas memperlihatkan bahwa talempong bukan sekedar bunyi hiburan atau keramaian saja, akan tetapi mempunyai makna ada suatu kebesaran. Talempong adalah simbol kebesaran, karena di situ menggambarkan seperti raja yang datang.

Suasana tersebut membuat masyarakat yang rumahnya dilewati arak-arakan akan mengintip dari balik jendela rumah mereka, atau bahkan turun ke halaman rumah menyaksikan arakarakan. Masyarakat penonton yang menyaksikan dari dalam rumah, halaman, atau para laki-laki yang sedang berada di lapau-lapau yang dilewati memperhatikan seluruh pelaku upacara, mulai dari anak pisang, perempuan-perempuan bako pelaku upacara, dan kelompok talempong bundo sebagai satu-satunya musik yang dihadirkan dalam prosesi tersebut. Di sini muncul sebuah nilai berdasarkan konstruksi masyarakat penonton, tentang besarnya perhatian dan tanggung jawab induak bako terhadap anak pisangnya.

Pertunjukan talempong bundo yang merupakan bagian dari struktur arak-arakan maanta padi saratuih ini dilaksanakan menjelang waktu shalat Zuhur (pukul 11.00 W.I.B.). Suara talempong yang hadir pada tengah hari tersebut merupakan suara yang mengisi ruang bunyi Nagari Singkarak. Kadangkala suara talempong tumpang tindih dengan suara alunan ayat-ayat suci Al-Qur'an yang diperdengarkan dengan pengeras suara dari Mesjid, atau bahkan suara azan untuk sholat Zuhur. Waktu yang dipilih untuk penyelenggaraan upacara itu telah menjadi kesepakatan masyarakat setempat.

Ketika arak-arakan melewati jalan raya, suara talempong berpadu dengan suara lalu lintas kendaraan di jalanan yang juga membuat suasana menjadi berbeda. Tanpa sengaja pertunjukanpun menjadi tontonan bagi para pemakai jalan raya. Kadangkala jalan raya propinsi yang melewati Nagari Singkarak menjadi macet beberapa saat karena arakarakan. Namun suasana tersebut sama sekali tidak mempengaruhi aktifitas musisi talempong bundo dan seluruh pelaku arak-arakan.

Semua pelaku arak-arakan berjalan tenang diiringi bunyi-bunyian komposisi musik talempong bundo yang bertempo cenderung cepat. Ekspresi para musisi talempong tersebut sejalan dengan ekspresi wajah seluruh pelaku upacara yang kelihatan amat tenang dan sederhana. Ekspresi ini sesuai dengan sifat dan karakter perempuan Minang yang amat terbatas dan tidak berlebihan. Mereka menjalankan pertunjukan sebagaimana kebiasaan dan rutinitas pekerjaannya sehari-hari dalam rumah tangga. Ekspesi masing-masing pelaku upacara tersebut disatukan oleh sajian musik talempong bundo sehingga membentuk satu kesatuan simbol yang mengantarkan para penikmatnya berhubungan dengan alam semesta. Pengungkapan ekpresi para musisi tersebut tidak berpengaruh terhadap tempo lagu (gua), sehingga tempo lagu dari awal hingga akhir pertunjukan selalu konstan 
dan hampir tidak berubah sama sekali. Ini sejalan dengan pendapat Turner bahwa ekspresi merupakan pengungkapan kristalisasi dari suatu pengalaman hidup manusia. Menurut Bruner (Mistortoify, 2010: 1), ekpresi selalu mempunyai hubungan dengan pengalaman budaya masyarakatnya.
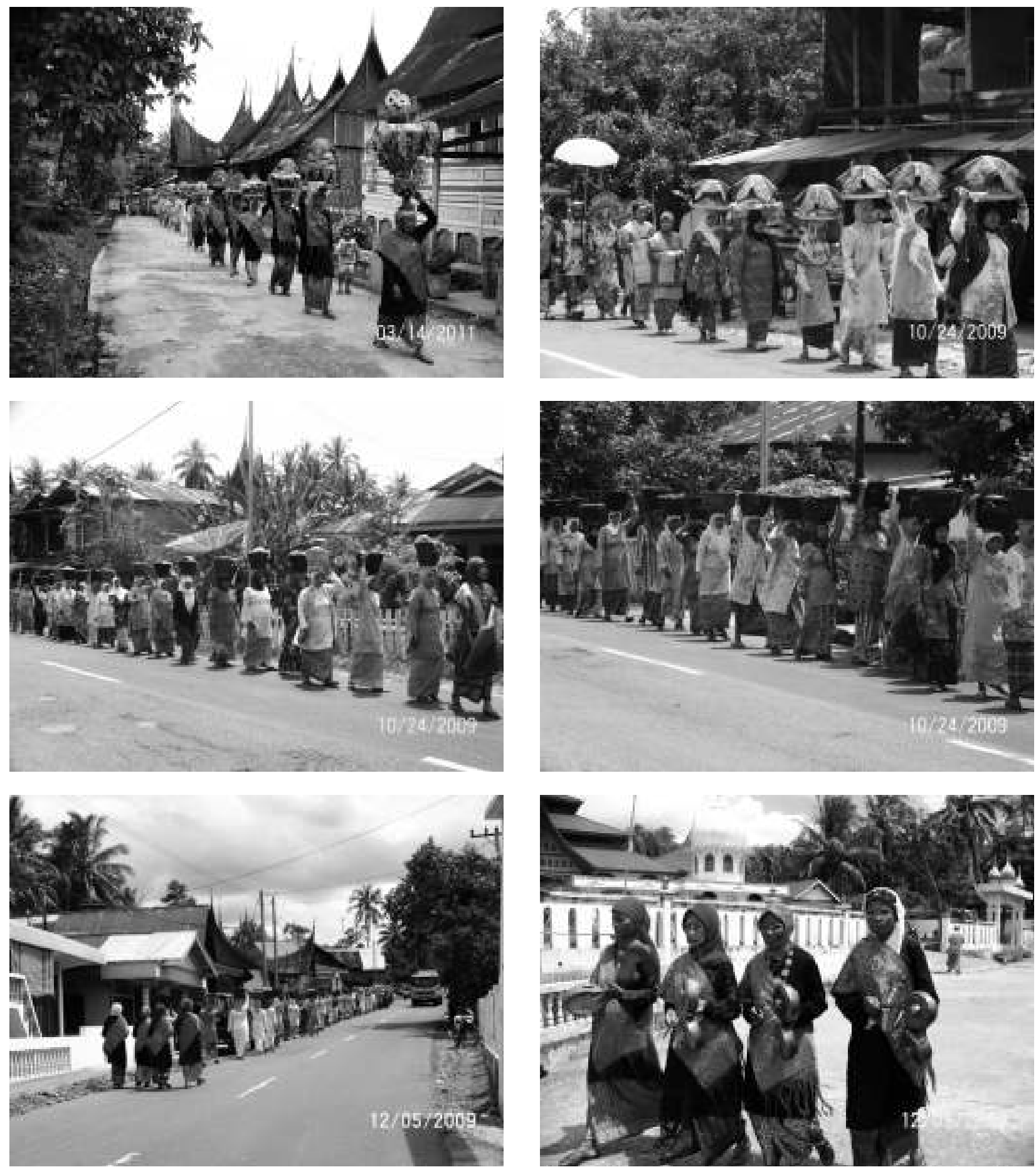

Gambar 7. Arak-arakan maanta padi saratuih yang terdiri dari penjunjung oyak osen, jamba, nasi putiah, nasi kunyik, kambuik balamun (a), penjunjung talam sumandan, pasumandan-pasumandan mudo, anak pisang (anak daro/ marapulai) dan induak bako (pendamping) (b), penjunjung kambuik karambia (c), penjunjung kambuik padi (d), dan pemain talempong bundo (e dan f) (Foto: Wilma Sriwulan, 2009-2011) 
perempuan-perempuan yang sudah menikah, ini menekankan bahwa tidak ada perempuan yang belum menikah yang hadir dalam upacara itu. Dengan tidak terlibatnya perempuanperempuan yang belum menikah memperlihatkan bahwa upacara ini merupakan tanggung jawab penuh dari bundo kanduang (ibu sejati), adalah perempuan-perempuan yang dihormati dan dimuliakan di dalam masyarakat.

Sepanjang perjalanan upacara, para musisi talempong bundo yang terdiri atas pemain talempong anak, tangah, induak, dan pemain adok terus menerus memainkan gua-gua yang mereka kuasai. Gua-gua yang dimainkan mungkin saja hanya sebagian kecil dari seluruh perbendaharaan gua yang ada di dalam kelompok talempong bundo tersebut. Pada saat-saat tertentu, keempat pemain saling mengisyaratkan untuk mengakhiri repertoar yang sedang dimainkan. Tempo dan pola permainan mendadak diturunkan untuk menutup repertoar tersebut, sampai akhirnya semua alat berhenti bermain. Setelah berhenti beberapa saat, pada waktu berikutnya repertoar segera diganti dengan gua yang lain, dan gua yang dipilih inipun sesuai dengan gua yang diusulkan pemain talempong induak. Pemain talempong anak yang selalu mengawali permainan kembali memainkan alat musiknya yang diikuti oleh pemain talempong tangah, induak, dan adok. Keempat musisi talempong bundo tersebut kembali hanyut ke dalam gua yang sedang dimainkan. Mereka bermain saling isi mengisi mengikuti irama gua yang dipilih dengan teknik permainan yang bapilin (interlocking). Saat-saat yang paling sempurna dari segi musik adalah dihasilkannya suatu campuran ritme bersinkop yang seimbang, selaras dengan irama langkah rombongan arak-arakan upacara maanta padi saratuih yang berjalan pelan. Situasi ini terjadi hingga pertunjukan talempong dan arak-arakan itu sampai di rumah anak pisang.

Kadangkala kelompok talempong bundo ini berpapasan dengan kelompok talempong bundo lainnya yang juga sedang mengiringi upacara maanta padi saratuih dari keluarga yang berbeda. Dalam situasi ini, setiap kelompok tetap berusaha mempertahankan keterpaduan ritmis dan temponya masing-masing tanpa terpengaruh dengan kelompok talempong lainnya.

Dengan dukungan busana adat bundo kanduangyangberwarnahitam dan berselempang merah, kelompok talempong bundo kelihatan semakin berkharisma berada di dalam arakarakan. Apalagi jika dipadukan dengan busana anak pisang sebagai pengantin dan busana seluruh pelaku upacara, terlihat perpaduan suasana yang amat kontras dan menarik untuk diamati. Busana-busana seluruh pelaku arakarakan secara visual selain menggambarkan posisi dan fungsi sosial masing-masing, juga memungkinkan masyarakat penonton untuk mengenali posisi mereka di dalam kekerabatan keluarga induak bako. Perpaduan busana bundo kanduang yang memadukan warna merah dan hitam, busana pasumandan-pasumandan mudo yang menggunakan warna dominan merah, dan warna busana anak pisang sebagai pengantin yang secara tradisional memiliki bentuk yang jelas dan mempunyai makna yang dalam. Busana-busana tersebut hanya dipergunakan dalam pertemuan-pertemuan besar seperti dalam upacara ini.

Pertunjukan talempong bundo dan seluruh prosesi yang melibatkan bako-bako perempuan yang sudah menikah itu berlangsung sekitar 45 menit. Pertunjukan berakhir setelah seluruh pelaku arak-arakan sampai ke rumah anak pisang, dan seluruh persembahan bako diterima oleh pihak anak pisang beserta kaum kerabat. Dalam upacara ini, terlihat berbagai macam simbol, seperti diungkapkan oleh Turner (1982: 21-22) bahwa: "Simbol ritual menjadi sebuah faktor dalam tindakan sosial, suatu kekuatan positif dalam bidang aktifitas. ... simbol terkait dengan kepentingan manusia, tujuan, sasaran dan sarana, aspirasi dan ide-ide, individu dan kolektif, apakah ini dirumuskan secara tegas atau harus disimpulkan dari tingkah laku yang diamati”

Keterlibatan induak bako dalam upacara ini sebagai wujud pelepasan anak pisangnya dari seorang gadis menuju kedewasaan, menuju jenjang perkawinan. Namun status anak pisang sebagai seorang istri atau seorang suami belum 
bisa dijalankan sebelum menyelesaikan ritus perkawinannya secara utuh. Secara keseluruhan proses ritual maanta padi saratuih dapat dilihat seperti gambar 8 .

Dapat dipahami bahwa sesungguhnya terjadi tiga proses. Pertama, induak bako menjemput anak pisang ke rumah orang tuanya; kedua, anak pisang dibawa ke rumah bako, kemudian dimandikan dalam ritual mandi balimau, setelah itu anak pisang dirias dan dipasangkan pakaian pengantinnya; dan ketiga, induak bako mengantarkan anak pisang kembali ke rumah orang tuanya dengan arak-arakan maanta padi saratuih. Dari proses tersebut kembali ditemukan struktur tiga lainnya yang saling berkesejajaran, anak pisang dijemput, dibawa, dan diantarkan kembali.

\begin{tabular}{|c|c|c|c|c|}
\hline Dijemput & $:$ & Dibawa & $:$ & $\begin{array}{c}\text { Diantarkan } \\
\text { kembali }\end{array}$ \\
\hline
\end{tabular}

Struktur tiga di atas berjalan secara fungsional, sehingga ketika bako akan melaksanakan upacara maanta padi saratuih, ia harus menjemput anak pisangnya lebih dulu, selanjutnya anak pisang dibawa ke rumah bako, kemudian diantarkan lagi. Secara fungsional induak bako ingin menunjukkan eksistensinya, jadi perlu ada peristiwa penjemputan anak pisang dari rumah orangtuanya ke rumah bako. Pola-pola tiga ini menunjukkan induak bako mempunyai peranan yang amat penting dalam upacara maanta padi saratuih. Ini merupakan salah satu ciri matrilineal Minangkabau. Sebagaimana diungkapkan oleh Lévi-Strauss (Koentjaraningrat, 1987: 213-214) bahwa masyarakat bersahaja biasanya didominasi oleh sistem kekerabatan, dan seluruh warga berinteraksi di dalamnya berdasarkan system simbolik yang menentukan sikap mereka terhadap paling sedikit tiga kelas kerabat, yaitu kerabat karena hubungan darah, karena hubungan kawin, dan karena hubungan keturunan. Hubungan tali kerabat induak bako dan anak pisang (hubungan antara seorang perempuan dengan anak saudara laki-lakinya) dalam sistem kekerabatan matrilineal Minangkabau adalah salah satu contoh hubungan yang terjadi karena hubungan kawin. Dalam masyarakat matrilineal hubungan ini menurut analisis Lévi-Strauss (Koentjaraningrat, 1987: 214-215) bersifat negatif, karena berdasarkan sikap sungkan, resmi, dan menghormat. Berbeda dengan hubungan seseorang perempuan dengan anak saudara perempuannya yang dianggap bersifat positif karena didasarkan sikap bersahabat dan mesra.

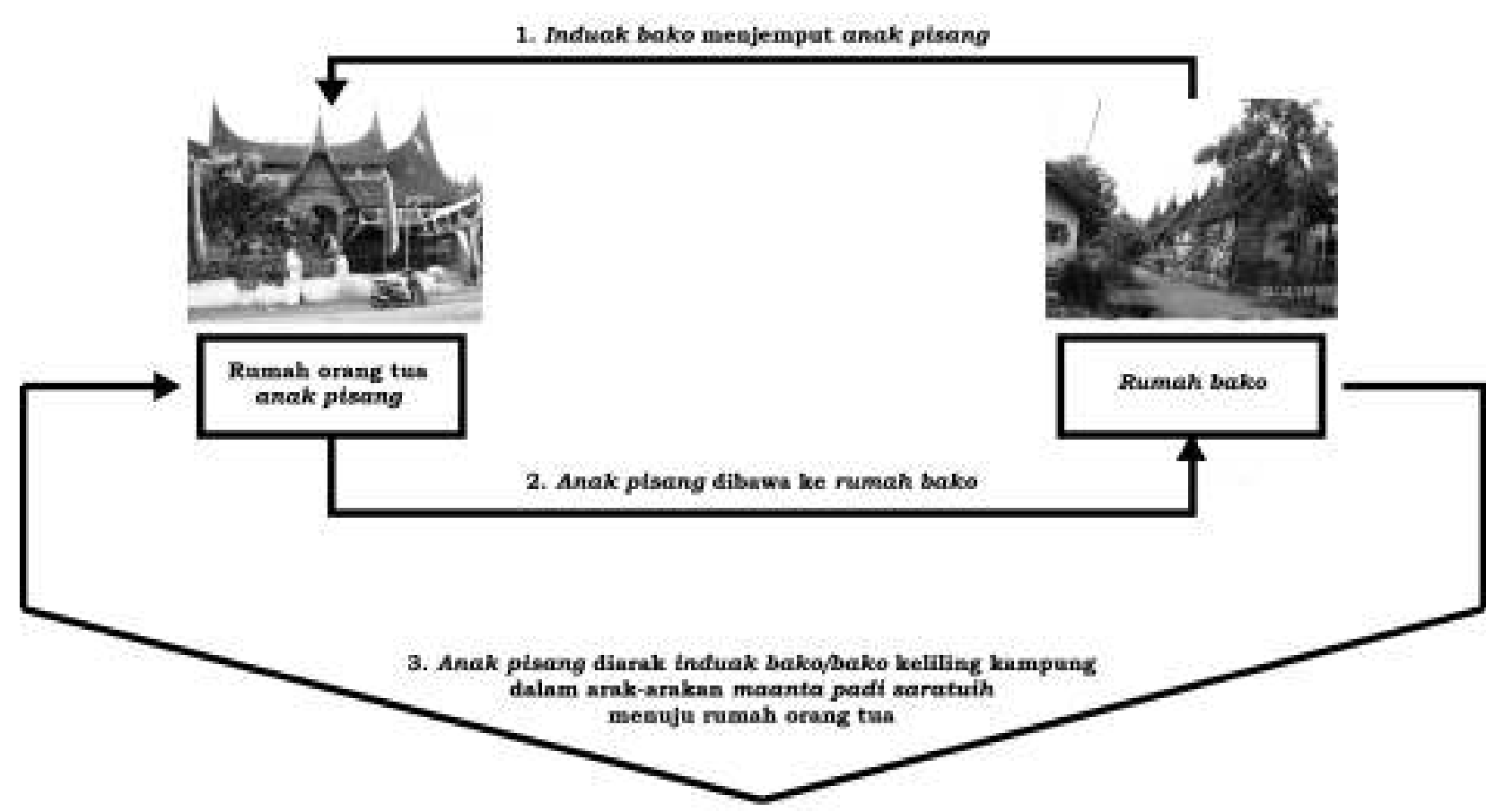

Gambar 8. Proses pelaksanaan upacara maanta padi saratuih 
Fenomena upacara maanta padi saratuih yang dilaksanakan oleh induak bako terhadap anak pisangnya ini menunjukkan rasa perhatian dan tanggungjawab induak bako terhadap anak pisang. Seperti yang diungkapkan Loeb (de Jong, 1960: 65) bahwa pada umumnya perkawinan dianggap sebagai event yang sangat penting, sehingga banyak upacara yang berkaitan dengan perkawinan biasanya dilaksanakan. Induak bako mempunyai kewajiban dalam upacara-upacara tersebut. Mereka sangat menghormati anak pisang, pada berbagai upacara tersebut mereka memberikan hadiah kepadanya.

Pada sisi lain, ritual maanta padi saratuih dapat dikatakan sebagai tahap transisi bagi anakpisang, sebagaimana diungkapkan oleh Van Genep (Turner, 1982: 24-26) bahwa transisi disebut liminoid, berarti meninggalkan satu pos untuk menuju pos lain. Turner memperjelas tahap liminalitas ini menjadi tahap refleksi formatif, artinya dalam tahap ini si subjek ritual diberi waktu untuk merefleksikan ajaran-ajaran dan adat istiadat masyarakat. Dengan merefleksi diharapkan, dia dibentuk menjadi anggota masyarakat yang baru. Di sini ada perubahan baik pandangan maupun kedudukannya (Winangun, 1990: 31). Dalam hubungannya dengan anak pisang, tahap transisi atau liminoid di sini adalah bahwa anak pisang pada ritual pernikahannya belum meninggalkan masa gadisnya, tetapi belum juga menapaki masa pernikahannya. Musik talempong bundo dalam ritual ini merupakan salah satu simbol yang menyuarakan tahap liminalitas posisi anak pisang tersebut.

Kehadiran talempong bundo dalam upacara maanta padi saratuih merupakan suatu tindakan yang diharuskan oleh adat kebiasaan masyarakat setempat. Penampilan dan kehadiran talempong bundo dalam upacara tersebut berfungsi mengkomunikasikan kepada masyarakat setempat bahwa ada anak pisang yang sedang berganti status. Selain itu juga berfungsi untuk menghidupkan dalam pikiran masyarakat suatu sistem sentimen tertentu yang sangat penting guna mengatur hubungan di antara kedua kelompok keluarga. Adapun gua-gua (lagu) yang dimainkan oleh musisi talempong bundo dalam upacara maanta padi saratuih siang itu terdiri atas: 1) Gua Rami; (2) Gua Rantak Kudo; dan (3) Gua Kijang Balari.

Peristiwa pertunjukan talempong bundo mulai dari merias anak pisang hingga dalam maanta padi saratuih dianggap sebagai sebuah pertunjukan yang terdiri dua bagian. Pada bagian pertama saat merias anak pisang dimainkan tiga gua yang terdiri atas: 1. Gua Rami; 2) Gua Tari Piriang; dan 3) Gua Pulang Baliak. Kemudian dalam arak-arakan maanta padi saratuih dimainkan juga tiga gua, yaitu: 1) Gua Rami; (2) Gua Rantak Kudo; dan (3) Gua Kijang Balari.

Struktur pertunjukan talempong bundo berdasarkan gua yang dimainkan saat merias anak pisang dan dalam arak-arakan maanta padi saratuih dapat dilihat seperti gambar 9.

Dari gambar 9 terlihat bahwa Gua Rami selalu dimainkan oleh para musisi talempong bundo pada kedua peristiwa tersebut. Gua Rami (G1) dimainkan talempong bundo saat merias anak pisang, Gua Rami (G1') juga dimainkan dalam arak-arakan maanta padi saratuih. Fenomena ini memperlihatkan bahwa Gua Rami merupakan gua pembuka dari setiap pertunjukan talempong bundo.

Dalam pandangan adat atau kehidupan sosial Minangkabau dalam suatu nagari bahwa pelaksanaan suatu konteks upacara adat yang

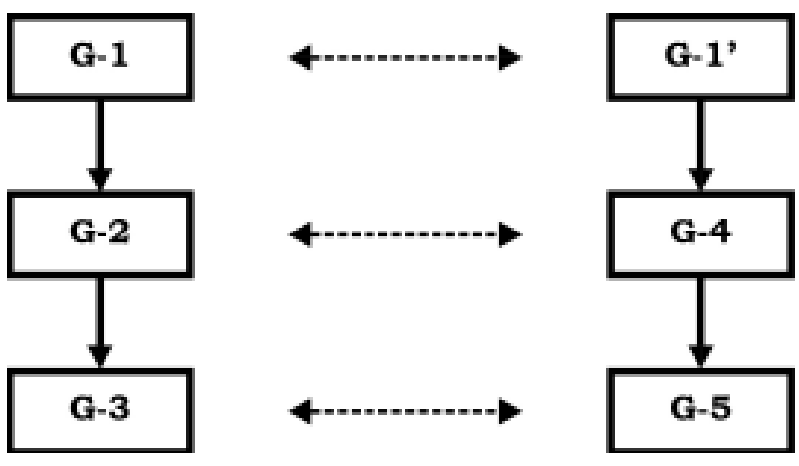

Keterangan:

G1 = Gua Rami

$\mathrm{G} 2=$ Gua Tari Piriang

G3 = Gua Pulang Baliak

G4 = Gua Rantak Kudo

G5 = Gua Kijang Balari

Gambar 9. Struktur gua yang dimainkan talempong bundo saat merias anak pisang dan maanta padi saratuih 
melibatkan orang banyak disebut sebagai 'sebuah keramaian' (asal katanya 'ramai' atau 'rami' dalam bahasa Minang). Keterlibatan orang banyak tersebut misalnya sebagai pelaksana upacara, maupun yang berposisi sebagai panggilan adat (undangan adat), atau pun orang banyak yang berposisi sebagai penonton saja. Dalam etika sosial masyarakat nagari, kehadiran suatu keramaian di tengah upacara adat termasuk peristiwa penting yang harus dihormati oleh semua masyarakat yang hadir sebagaimana tercantum pada poin ke enam dalam Undang Undang Nan Sembilan Pucuk yang berbunyi "Undang-undang yang takluk kepada keramaian" (Sanggoeno dalam Hajizar, 2002: 25; Suarman, dkk, 2000: 225; dan Sango, 1959: 10). Salah satu keramaian yang istimewa dalam kehidupan sosial masyarakat Nagari Singkarak ialah pelaksanaan upacara maanta padi saratuih oleh pihak induak bako terhadap seorang anak pisang yang disempurnakan pelaksanaannya oleh dukungan penyajian musik talempong bundo.

Bagi masyarakat Nagari Singkarak khususnya, terutama bagi kelompok talempong bundo, karakter suasana keramaian dalam rangkaian pelaksanaan upacara maanta padi saratuih beranalogi pada karakter repertoar lagu Gua Rami. Gua Rami merupakan sebuah komposisi musik talempong bundo versi Nagari Singkarak yang menghasilkan karakteristik yang terkesan ramai (rami) dan ceria. Gua Rami ini juga merupakan representasi rasa kegembiraan induak bako melalui 'bunyibunyian' komposisi musik kelompok talempong bundo yang sekaligus juga merepresentasikan suasana hati dan psikologis pihak induak bako. Betapapun mahirnya kualitas teknis permainan suatu kelompok talempong laki-laki yang ada di Nagari Singkarak tidak akan bisa mewakili jiwa kebesaran talempong bundo sebagai kelompok musik perempuan yang ada di daerah tersebut.

\section{Fungsi dan Makna Talempong Bundo dalam Upacara Maanta Padi Saratuib}

Upacara maanta padi saratuih menjadi salah satu upacara adat yang termasuk klasifikasi penting dalam kehidupan sosial masyarakat Nagari Singkarak. Upacara ini mengandung makna dan arti penting yang tinggi bagi masyarakat, khususnya masyarakat yang mengetahui dan memahami keberadaan, hakekat, dan fungsi upacara ini. Hak dan legalitas upacara maanta padi saratuih terletak pada pihak induak bako (bako kontan), sedangkan anak pisang menjadi obyek upacaranya, karena induak bako sebagai bako kontan langsung memiliki keterkaitan tali darah dengan sang anak pisang perempuan atau laki-laki yang sedang melangsungkan rangkaian tradisi perkawinannya. Oleh karena legalitas pelaksanaan upacara maanta padi saratuih terletak pada institusi adat induak bako, maka secara adat induak bako bertanggung jawab penuh untuk menyiapkan skenario upacara. Induak bako langsung mengelola upacara tersebut semenjak persiapan, pelaksanaan, hingga selesai. Segala skenario untuk pelaksanaan upacara itu dipersiapkan sebelumnya.

Segala dana dan bawaan pada prosesi dengan segala spesifikasi yang diperlukan sebagai dampak dari pelaksanaan upacara juga ditanggung langsung dan dikoordinasi oleh induak bako. Induak bako akan merancang biaya yang dibutuhkan untuk pelaksanaan upacara maanta padi saratuih ini. Bahkan induak bako sudah menabung padi semenjak panen terakhir dalam rangka menyambut rencana pernikahan anak pisangnya. Induak bako merencanakan persiapan jamba adat, lengkap dengan para pelaku upacara maanta padi saratuih sesuai dengan aturan adat yang berlaku di Nagari Singkarak.

Dalam rangka ini induak bako akan menghubungi secara adat perempuan-perempuan pihak induak bako jauh hari sebelum upacara maanta padi saratuih dilaksanakan. Induak bako juga akan menentukan kelompok musik talempong bundo yang akan diundang untuk menjadi bagian struktur pendukung upacara maanta padi saratuih. Selanjutnya induak bako juga menentukan jadwal serta bako yang akan menjemput dan membawa anak pisang dari rumah keluarganya ke rumah bako, kemudian mengantarkan anak pisang kembali dalam arakarakan maanta padi saratuih. Semua item penting tersebut merupakan rangkaian dari sub-sub bagian pelaksanaan upacara maanta padi saratuih semenjak persiapan hingga berakhirnya upacara tersebut. 
Agar pelaksanaan upacara berjalan dengan lancar, biasanya persiapan upacara hingga selesai dipimpin oleh nenek bako (orang tua dari ayah). Akan tetapi jika nenek bako sudah tidak ada biasanya pihak induak bako menunjuk seorang bundo kanduang atau seseorang perempuan dalam suku induak bako itu yang sudah berpengalaman untuk memimpin segala pelaksanaan upacara semenjak dari persiapan hingga berakhirnya upacara maanta padi saratuih. Tanpa dipimpin oleh seorang yang berpengalaman pelaksanaan upacara sangat berpeluang tidak berhasil. Kegagalan upacara akan berakibat bisa mengecewakan anak pisang dan pihak keluarganya, bahkan mengecewakan masyarakat yang menyaksikan jalannya upacara. Seandainya pelaksanaan upacara maanta padi saratuih tidak berjalan dengan baik (tidak berhasil), maka akan timbul kembali kritik sosial oleh masyarakat terhadap pihak induak bako. Induak bako akan mendapat malu di tengah masyarakat nagari, karena dianggap tidak serius mempedulikan anak pisangnya.

Induak bako dan bako-bako perempuan lainnya langsung berposisi sebagai tokoh-tokoh pelaku upacara maanta padi saratuih sesuai dengan struktur posisi dan urutan dalam prosesi arak-arakan upacara itu. Ketentuannya sangat berhubungan dengan hirarki tertentu sesuai dengan jenis dan spesifikasi properti adat yang dibawa dalam arak-arakan. Seperti telah dipaparkan pada bagian sebelumnya bahwa spesifikasi bawaan atau properti adat dan posisi urutan para pelaku upacara terdiri atas penjunjung oyak osen, jamba adat, nasi putiah, nasi kunyik; kelompok penjunjung kambuik balamun, talam sumandan; kelompok pasumandan mudo, anak pisang (anak daro/marapulai) beserta dua orang induak bako pendamping, kelompok pasumandan mudo; kelompok penjunjung kambuik karambia, kambuik padi; dan kelompok musisi talempong bundo.

Spesifikasi bawaan adat yang paling penting adalah menempati urutan paling depan yang langsung diperankan oleh perempuan-perempuan senior dari induak bako (bako kontan) tersebut, sekaligus untuk menunjukkan eksistensinya sebagai induak bako. Sedangkan urutan kepentingan spesifikasi bawaan adat selanjutnya langsung menyesuaikan diri sesuai dengan peran yang dibawanya. Berbeda dengan posisi pelaku musik tradisional talempong bundo, kelompok musisi ini diundang secara khusus untuk menjadi bagian struktur upacara sekaligus mendukung pelaksanaan upacara maanta padi saratuih. Kelompok musik talempong bundo dalam hal ini menempati posisi urutan tertentu pada bagian belakang arak-arakan sesuai dengan karakter dari suatu iring-iringan prosesi arak-arakan tersebut. Demikian juga halnya dengan perempuan pembawa oyak osen sebagai kepala adat menempati posisi paling depan dalam upacara tersebut.

Induak bako langsung bertugas sebagai pelaksana upacara, karena dalam suatu pelaksanaan upacara adat di Nagari Singkarak tidak ada istilah "mancari angok kalua badan" (mencari nafas keluar tubuh). Maksudnya minta bantuan kepada orang lain di luar suku bako itu sendiri untuk menjadi pelaksana upacara maanta padi saratuih, baik dalam urusan jamba atau konsumsi adat, maupun dalam pelaksanaan prosesi arak-arakan dan tokoh-tokoh pelakunya. Seorang mamak (saudara laki-laki ibu) atau bundo kanduang dalam suku induak bako itu akan merasa malu bila pelaku dan pelaksana dalam suatu upacara adat itu diperankan atau dikerjakan oleh orang lain yang tidak sesuku dan tidak ada hubungan secara adat dengan pihak induak bako tersebut. Artinya semua pelaku dalam suatu upacara adat, baik seseorang itu menempati posisi yang sedikit penting hingga menempati posisi yang penting selalu diperankan oleh individu atau orangorang yang bertalian darah atau bertalian secara adat. Begitulah sistem yang berlaku menurut adat di Nagari Singkarak. Di sini akan terlihat sekali bagaimana komunikasi adat dan rasa kekompakan pihak bako dalam menjalin silaturahim dalam kelompok adat mereka.

Dengan demikian, berdasarkan fakta sosial dari kesaksian masyarakat terhadap dampak pelaksanaan upacara maanta padi saratuih, maka pihak induak bako akan selalu mempersiapkan upacara maanta padi saratuih dengan sehati-hati mungkin dan selengkap mungkin. Misalnya tentang volume besarnya bawaan adat mereka akan dipersiapkan melebihi ukuran normal secara adat, dan akan dibawa pula oleh peserta arak-arakan 
dengan properti yang bervariasi sehingga prosesi arak-arakan terkesan megah. Oleh sebab itu besar dan megah, serta lebih panjangnya prosesi arakarakan upacara lengkap dengan musik prosesi talempong bundo menggambarkan simbol sosial atau kesejahteraan sebagai kebanggaan pihak induak bako perempuan.

Bagi pihak induak bako (bako kontan) bila telah memiliki anak pisang (perempuan atau lakilaki) berarti sudah langsung tertumpang tanggung jawab kepadanya selaku induak bako. Ini menjadi salah satu bukti terjadinya hubungan tali darah dan silaturahim yang terbangun dari hasil perkawinan antara dua jenis insan (laki-laki dan perempuan) yang berasal dari dua keluarga dan suku yang berbeda (keluarga dan suku bako dari pihak ayah, keluarga dan suku anak pisang dari pihak ibu). Pada saat anak pisang (laki-laki atau perempuan) melangsungkan tradisi perkawinan maka di sinilah induak bako menunjukkan tanggung jawabnya terhadap anak pisang. Induak bako wajib melaksanakan upacara maanta padi saratuih sebagai simbol sistem kekerabatan hubungan tali darah dalam bentuk tanggung jawab adat. Dengan demikian, pelaksanaan upacara maanta padi saratuih bersama musik prosesi talempong bundo merupakan seremonial upacara adat yang menggambarkan telah terlaksananya tanggung jawab adat oleh pihak induak bako terhadap anak pisangnya. Seremonial upacara adat ini akan disaksikan oleh mata penonton yang ramai (bagalanggang mato rang banyak) yang berada dalam Nagari Singkarak.

Pelaksanaan upacara-upacara adat yang lain di Nagari Singkarak tidak sebesar dan sekompak pelaksanaan upacara maanta padi saratuih. Sehingga upacara maanta padi saratuih dari komunitas pihak induak bako (bako kontan) ataupun bako jauh (yang tidak kontan) akan terlaksana dengan penuh kekompakan dan kedamaian. Dengan demikian sinergi peserta arak-arakan bersama musik prosesi talempong bundo menjadi simbol silaturahim antara pihak induak bako dengan pihak anak pisang.

Bagi masyarakat Nagari Singkarak, kehadiran talempong bundo dalam upacara maanta padi saratuih menjadi satu-satunya 'bunyi-bunyian' yang hadir dalam prosesi arak-arakan upacara tersebut.
Talempong bundo baru dapat dikatakan memiliki makna ketika mulai dimainkan dan bunyinya di dengar oleh anak pisang, induak bako, bako, dan masyarakat sekitar. Dalam pengertian ini, kehadiran talempong bundo sudah terikat dengan sistem upacara maanta padi saratuih, sebagai bagian dari sistem sosial masyarakat Nagari Singkarak. Bunyibunyian talempong bundo dalam hal ini menjadi simbol kebesaran bagi upacara adat tersebut.

Fungsi utama kehadiran kelompok talempong bundo adalah menjadi bagian dari struktur upacara maanta padi saratuih. Kehadiran musik yang memiliki daya tarik tersendiri tersebut bertujuan untuk membangun suatu suasana yang bersahaja dalam kemeriahan, kegembiraan, dan sebagainya. Di samping itu, fungsi spesifik dari kehadiran kelompok talempong bundo dan sajian komposisi musik yang dimainkannya ialah terbangunnya rasa silaturahim yang akrab antara individu atau antara paruik (orang-orang yang berada dalam satu nenek) dan pabisan (ipar dan besan) di dalam suku induak bako tersebut. Karena dalam suasana upacara maanta padi saratuih ini pulalah antara paruik dengan paruik dalam suku induak bako, antara para pasumandan dengan induak bakolbako sebagai pabisannya (atau sebaliknya) saling bertemu dan melakukan prosesi arak-arakan maanta padi saratuih.

Suasana kebesaran upacara adat yang terbangun oleh bunyi-bunyian talempong bundo berfungsi sebagai 'penyatuan suasana upacara' sehingga mempererat nilai kekerabatan matrilineal anak pisang terhadap bako perempuan. Meriah dan gegap gempitanya suasana iring-iringan prosesi maanta padi saratuih dibangun oleh bertalunya sajian bunyi-bunyian komposisi musik oleh kelompok musisi tradisional talempong bundo. Kesatuan suasana yang terbangun oleh sajian musik ini akan memberikan kesan bahwa peristiwa langka upacara maanta padi saratuih ini hanya berlangsung sekali seumur hidup bagi anak pisang.

Kemegahan seremonial upacara melalui dukungan musik prosesi talempong bundo terkandung nilai spirit terhadap anak pisang dalam konteks upacara maanta padi saratuih. Selain menambah kentalnya keakraban anak pisang dengan induak bakonya, kemegahan suasana 
prosesi arak-arakan didukung oleh kharisma bunyibunyian talempong bundo. Permainan talempong yang tingkah-bertingkah oleh kecekatan tangan para ibu-ibu bundo kanduang tersebut juga telah membangun nilai spirit terhadap jiwa seorang anak pisang yang sedang melangsungkan rangkaian ritual perkawinannya. Dalam arti kata perasaan hati seorang anak pisang selaku anak daro atau marapulai saat itu dalam keadaan berdebar-debar disebabkan akan memulai hidup berumah tangga yang penuh dengan misteri. Akan tetapi suasana upacara maanta padi saratuih yang seremonial dibangun oleh sajian musik tradisional talempong bundo dapat dikatakan sebagai simbol dukungan moral induak bako terhadapnya sebagai anak pisang. Suasana musik tersebut sekaligus menambah kekuatan atau spirit tersendiri terhadap anak pisang yang sedang menempuh hidup baru dalam dunia kekeluargaan yang baru. Di sini anak pisang betul-betul merasa memiliki induak bako yang bertanggung jawab dan selalu memperhatikan anak pisangnya. Ia akan mengantarkan anak pisangnya ke jenjang pelaminan masa perkawinan anak pisang. Melalui situasi ini akan terbangunlah nilai kebanggaan anak pisang terhadap induak bakonya.

Fenomena-fenomena di atas memperlihatkan bahwa masyarakat Nagari Singkarak memiliki kebanggaan khusus terhadap peran dan posisi kaum perempuan baik sebagai pelaku seni maupun pelaku adat di dalam kehidupan sosial di nagari tersebut. Kehadiran talempong bundo dalam konstruksi masyarakat khas Nagari Singkarak telah mengapungkan "kebanggaan khusus" terhadap kekhasan upacara adat masyarakat nagari tersebut di tengah kehidupan sosial adat masyarakat Minangkabau umumnya.

\section{Penutup}

Kehadiran kelompok talempong bundo dalam upacara maanta padi saratuih amat penting, karena tidak ada upacara yang dilaksanakan tanpa kehadiran talempong bundo. Posisi kelompok talempong bundo tersebut tidak bisa tergantikan oleh kelompok lainnya, seperti kelompok talempong anak mudo sebagai kelompok musik laki-laki yang ada di Nagari Singkarak, walaupun figur-figur pemain talempong anak mudo kelihatan lebih ekpresif dalam bermain musik. Kehadiran kelompok talempong anak mudo ini tidak akan bisa menyatu dalam keutuhan prosesi arak-arakan maanta padi saratuih yang didominasi oleh kaum perempuan. Artinya walaupun kualitas permainan kelompok talempong anak mudo lebih tinggi dibanding kelompok talempong bundo, namun tidak akan menjadi pertimbangan untuk mengikutsertakan talempong anak mudo dalam upacara maanta padi saratuih tersebut.

Tanpa bunyi-bunyian talempong bundo, maka prosesi arak-arakan maanta padi saratuih menjadi hambar, seolah-olah tidak menunjukkan greget. Tanpa bunyi-bunyian ini sekaligus meminimalisir ketebalan rasa kekerabatan pihak induak bako terhadap anak pisangnya, dan ini merupakan simbol spirit kekerabatan dalam konteks legitimasi.

Apabila diamati posisi talempong bundo dari segi struktur posisi arak-arakan maanta padi saratuih, sekilas terlihat bahwa kehadiran kelompok musik perempuan ini hanya sebagai pelengkap dari kesatuan kelompok arak-arakan saja. Karena pelaku-pelaku utama upacara ini sudah pasti dipegang oleh pihak induak bako dan bako-bako perempuan dengan segala ciri khas busananya. $\mathrm{Na}-$ mun demikian, bila kehadiran kelompok talempong bundo itu diamati dari sudut realitas kumandang bunyi yang dibangun oleh musik talempong tersebut, maka akan dihasilkan suasana yang agung dan kharismatik. Suasana upacara maanta padi saratuih yang demikian akan dirasakan oleh masyarakat penonton ataupun oleh kelompok iring-iringan prosesi maanta padi saratuih tersebut. Melalui kumandang bunyi-bunyian talempong bundo menunjukkan eksistensi induak bako masih fenomenal di Nagari Singkarak. Keberadaan talempong bundo dalam upacara maanta padi saratuih merupakan representasi sistem matrilineal dalam masyarakat Minangkabau di Nagari Singkarak.

\section{Kepustakaan}

Berger, Peter L.. 1985. Humanisme Sosiologi. Diterjemahkan oleh Daniel Dhakidae. Jakarta: PT. Inti Sarana Aksara.

De Jong. P.E. De Josselin. 1960. Minangkabau And Negri Sembilan: Socio-Political Structure 
In Indonesia. Djakarta: Bhatara.

Felicia Hughes-Freeland. 1998. Ritual, Performance, Media. New York: Routledge.

Hajizar. 2002. Menguak Konsep Musikal Tiga Jenis Talempong yang Langka di Luhak Limo Puluah Koto Minangkabau. Padangpanjang: Sekolah Tinggi Seni Indonesia.

Hendri, Yon. 2011. "Musik Keroncong Campur Sari dalam Pluralitas Budaya Masyarakat Sawahlunto" dalam Resital Jurnal Seni Pertunjukan. Volume 12 No. 1-Juni 2011: 84-95

Kato, Tsuyuki. 1982. Matriliny and Migration. Diterjemahkan oleh Azizah Kasim. Kuala Lumpur: Dewan Bahasa dan Pustaka.

Keesing, Rooger M. 1992. Antropologi Budaya: Suatu Perspektif Kontemporer. Jakarta: Erlangga.

Koentjaraningrat. 1987. Ritus Peralihan di Indonesia. Jakarta: PN. Balai Pustaka.

Koentjaraningrat. 1987. Sejarah Teori Antropologi. Jakarta: UI Press.

Mardimin, Johanes. 1994. "Rasionalisasi dalam Seni Tradisi", dalam Johanes Mardimin Jangan Tangisi Tradisi, Transformasi Budaya Menuju Masyarakat Indonesia Modern. Yogyakarta: Kanisius.

Mistortoify, Zulkarnain., Timbul Haryono, Lono L. Simatupang, dan Victorius Ganap. 2010. "Kèjhungan: Gaya Nyanyian Madura dalam Pemaknaan Masyarakat Madura Barat Pada Penyelenggaraan Tradisi Rèmoh" dalam Resital Jurnal Seni Pertunjukan. Vol. 11 No. 1, Juni 2010: 1-14.

Murgianto, Sal. 1996. "Cakrawala Pertunjukan Budaya Mengkaji Batas dan Arti Pertunjukan" dalam Jurnal Seni Pertunjukan Indonesia. Th. VII-1996: 153-167

Navis, A.A. 1984. Alam Terkembang Jadi Guru: Adat dan Kebudayaan Minangkabau. Jakarta: P.T. Grafiti Pers.

Pamoentjak, M. Thaib St. 1935. Kamoes Bahasa
Minangkabau - Bahasa Melajoe - Riau. Batavia: Departemen Van Onf derwijs en Eeredienst.

Radcliffe-Brown, A.R. 1980. Struktur dan Fungsi dalam Masyarakat Primitif. Diterjemahkan oleh Abd. Royak Yahya. Kuala Lumpur: Dewan Bahasa dan Pustaka Kementrian Pelajaran Malaysia.

Sango, Datoek Batoeah. 1959. Tambo Alam Minangkabau: Jaitu Asal Usul Minangkabau, Segala Peraturan Adat dan Undang-undang, Hukum di Segala Negeri yang Masuk Daerah Minangkabau. Pajakumbuh: Limbago.

Simatupang, GR Lono L. 2003 . "Reinterpretasi dan Reposisi Adat dan Tradisi: Bercermin dari Reyog Ponorogo". Makalah Dialog Budaya 'Revitalisasi dan Reinvensi Budaya Lokal Dalam Upaya Membangun dan Memperkokoh Jati Diri Bangsa', Proyek Pemanfaatan Kebudayaan Daerah, Badan Pengembangan Kebudayaan dan Pariwisata, Propinsi Daerah Istimewa Yogyakarta. Yogyakarta, 8-9 September. 2006. "Jagad Seni: Refleksi Kemanusiaan”. Makalah dalam Workshop "Seni Tradisi Lisan Sebagai Wahana Komunikasi yang Sangat Efektif di Tengah Masyarakat yang Sedang Berubah. Yogyakarta: Balai Kajian Sejarah dan Nilai Tradisional, 6 September.

Suarman, Bustanul Arifin, Syahrial Chan Dt. Bandaro Hitam. 2000. Adat Minangkabau Nan Salingka Hiduik. Solok: tp.

Turner, Victor. 1982. From Ritual To Theatre: The Human Seriousness of Play. New York: P.A.J. Publication.

1967. The Forest of Simbols: Aspects of Ndembu Ritual. Ithaca: Cornell University Press.

Winangun, Y.W. Wartaya. 1990. Masyarakat Bebas Struktur: Liminalitas dan Komunitas Menurut Victor Turner. Yogyakarta: Kanisius. 